\title{
Hygiene, sanitation and the soil transmitted helminths (STH) infection among elementary school students in West Lombok
}

\author{
Rahmawati $^{1 *}$, Soeyoko², Sri Sumarni² \\ ${ }^{1}$ Public Health Laboratory of Lombok Island, ${ }^{2}$ Departement of Parasitology, Faculty of Medicine, \\ Universitas Gadjah Mada, Yogyakarta
}

\begin{abstract}
The prevalenses of soil transmitted helminths (STH) infection in Lombok are relatively high. It is closley associated with poor environmetal hygiene, non healthy sanitation status, poverty and improper health services. The highest prevalences is normally observed in elementary school children. The aim of this study was to evalaute the relationship between hygiene, sanitation and STH infection among elementary school children in West Lombok. An observational study with cross-sectional design was performed involving 197 elementary school children in Terong Tawah Village, Labuapi Sub District, West Lombok District and 197 children in Ampenan, Mataram City as control. The stool specimen of the children were collected and processed using Kato-Katz technique. Hygiene and sanitation of each subject that consisted nail hygiene, hand washing, using footwear, latrine, clean water availability, house floor, soil around the house were taken by questionnaire and direct observation. The result showed that the prevalences of STH among elementary school children in Terong Tawah (81.7\%) was higher than that in Ampenan (12.7\%).Trichuris trichiura was the predominant helminth both in Terong Tawah (36.0\%) and Ampenan $(7.0 \%)$ followed by $A$. lumbricoides (20.4\% in Terong Tawah and $4.5 \%$ in Ampenan). The mix infections between $T$. trichiura and $A$. lumbricoides among the children in Terong Tawah (24.4\%) and Ampenan $(1.0 \%)$ were also found. A significant relationship between hygiene and sanitaion i.e. nail cleaniness, washing hands, contaminated soil around the house and STH infection among elementary school children in Terong Tawah and Ampenan $(\mathrm{p}<0.05)$. In conclusion, there is a significant relationship between personal hygiene, environmental sanitation and STH infections among elementary school children.
\end{abstract}

\section{ABSTRAK}

Prevalensi infeksi soil transmitted helminths (STH) di Lombok masih relatif tinggi. Hal ini berkaitan erat dengan kesehatan lingkungan yang rendah, kondisi sanitasi yang tidak sehat, kemiskinan dan pelayanan kesehatan yang kurang tepat. Prevalensi tertinggi infeksi STH umumnya terjadi pada anak sekolah dasar. Penelitian ini bertujuan untuk mengkaji hubungan antara kesehatan sanitasi dengan infeksi STH pada anak sekolah dasar di Lombok Barat. Penelitian observasi dengan rancangan potong lintang dilakukan dengan melibatkan 197 anak sekolah dasar di Desa Terong Tawah, Kecamatan Labuapi, Kabupaten Lombok Barat dan 197 anak sekolah dasar di Ampenan, Kota Mataram sebagai kontrol. Sampel tinja anak diambil dan diperiksa dengan metode Kato-Katz. Informasi kesehatan sanitasi masing-masing anak yang meliputi kesehatan kuku, kebiasaan cuci tangan, pemakaian alas kaki, kepemilikan jamban, ketersediaan air bersih, lantai rumah dan tanah sekitar rumah diperoleh dengan pemberian kuesioner dan pengamatan langsung. Hasil penelitian menunjukkan bahwa prevalensi infeksi STH anak sekolah dasar di Terong Tawah $(81,7 \%)$ lebih tinggi dibandingkan anak di Ampenan (12,7\%). Trichuris trichiura merupakan cacing penginfeksi utama baik Terong Tawah $(36,0 \%)$ dan Ampenan (7,0\%) diikuti dengan A. lumbricoides $(20,4 \%$ di Terong Tawah dan 4,5\%

\footnotetext{
$\overline{\text { * corresponding author: rahmawati_ikd@yahoo.co.id }}$
} 
di Ampenan). Infeksi campuran T. trichiura dan A. lumbricoides pada anak di Terong Tawah $(24,4 \%)$ dan Ampenan (1,0\%) juga ditemukan. Terdapat hubungan nyata antara kesehatan sanitasi yaitu kebersihan kuku, kebiasaan cuci tangan, tanah sekitar rumah yang terkontaminasi dengan infeksi STH pada anak sekolah dasar di Terong Tawah dan Ampenan $(p<0.05)$. Dapat disimpulkan, terdapat hubungan nyata antara kesehatan individu dan sanitasi lingkungan dengan kejadian infeksi STH pada anak sekoleh dasar.

Keywords: hygiene sanitation - soil transmitted helminths - infections - elementary school students - Kato-Katz method

\section{INTRODUCTION}

The Indonesia tropical climate is highly favourable to the persistance of helminths. Many species of helminth have been reported as causing infections in humans in Indonesia. However, only some of these species are highly prevalent and wideley distributed. One of them is intestinal helminth transmitted through soil (Soil Transmitted Helminths/STH). ${ }^{1,2}$ The most important STH infecting human in Indonesia are roundworm (Ascaris lumbricoides), hookworm (Ancylostoma duodenale and Necator americanus) and whip worm (Trichuris trichiura). ${ }^{2-4}$

The prevalences of STH infections in Indonesia are generally high. It is estimated that the prevalence of A. lumbricoides, T. trichiura, and hookworms are about $75 \%, 50 \%$, and $30 \%$, respectively. ${ }^{4,5}$ Lombok is an island in West Nusa Tenggara (Nusa Tenggara Barat or NTB) province, Indonesia where the prevalences of STH are relatively high. The prevalence of $A$. lumbricoides and $T$. trichiura are reported about $75 \%$ and $62 \%$, respectively. ${ }^{1}$ The high prevalences of STH infection in this region is closley associated with poor environmetal hygiene, non healthy sanitation status, poverty and improver health services. ${ }^{1,2}$

Chronic and intense STH infections can contribute to malnutrition and iron-deficiency anaemia, and also can adversely affect physical and mental growth in childhood. ${ }^{6-8}$ Moreover, the STH infections may contritube to impairenment cognitive function and educational achievement. ${ }^{3}$ In recognition of the global health importance of
STH infections, there is a renewed global commitment to finance and implement control strategies to reduce the disease burden of STH and other helminths. ${ }^{9}$

Directorate General of Desease Control and Environmental Health, Department of Health in Lombok has implemented a program for control and elimination of STH infections in 2010. However, the impact of the program to reduce STH prevalence in this region has not been evaluated, yet. Lack in health life style of schoolaged children, low healthy sanitation status and poor environmental hygiene are still observed in this area. This study reported the prevalence of STH infection in elementary school students in Terong Tawah Village, Labuapi Sub District, West Lombok District. In addition, risk factors of STH infection in this area were also reported.

\section{MATERIAL AND METHODS}

\section{Subjects}

An observational study with cross-sectional design was performed to evalaute the relationship between hygiene, sanitation and STH among primary school children in Terong Sawah Village, Labuapi Sub District, West Lombok District who met inclusion and exclusion criteria. The inclusion criteria was all selected primary school children who were living in the area of study for at least three months whose parents signed an inform consent and willing to participate in this study. The exclusion criteria primary school children who were having a history of being clinically ill and used drug 
within a period of one month before the study. Samples were collected through stratified random sampling. Based on the sample size estimation, a total of 394 samples were required for this study. As control, primary school children 44 Ampenan, Mataram City was chosen.

\section{Procedure of study}

On the day that has been agreed, subjects were gathered to be selected. The study including background, objectives and its benefits was explained to the teachers and the school children. Then each selected school children was provided with a labeled clean plastic container, a piece of applicator stick, a plain papaer and an inform consent. The children that, once they got home, they should give the inform consent to their parents to read and sign it if their parents agreed. The children were then instructed that if they were willing to participate in this study, in the morning of the next day, they should defecate on a piece of paper provided, to avoid contamination from the toilet environment, and then using an applicator stick they should pick up a portion of the stool on a piece of paper and put it into the clean plastic container provided and cover it, then come with it to school. The stool specimen were mixed immediately with $10 \%$ formalin to preserve the morphology of the eggs and taken to Health Polytechnic of Mataram, Ministry of Health for laboratory analysis. The stool specimens were then processed using Kato-Katz technique. ${ }^{10}$

To determine the number of worm eggs in fields, soil samples were collected from around the house of the children. The eggs were then extracted using $\mathrm{MgSO}_{4}$ floating method. The eggs in sedimenatation obtained from the method were then idetified and caunted under a light microscope. The number of eggs of each species were then converted into the number of eggs per gram of feces (EPG) in order to analyze intensity of infection. EPG were calculated by multiplying egg count by conversion factor i.e. 20. An infection status as mild, moderate or heavy infection created for the three common STH infections following the standard procedure used by WHO. ${ }^{11}$

Data about hygiene and sanitation of each subject consisted nail hygiene, hand washing, using footwear, latrine, clean water availability, house floor, soil around the house were taken by questionnaire and direct observation to the subject. The study has been approved by the Medical and Health Research Ethics Committee, Faculty of Medicine, Universitas Gadjah Mada, Yogyakarta.

\section{Statistical analysis}

Data were presented as frecuency distributions. Multivariate analysis was used to evaluate the relationship of hygiene, sanitation and STH infection. Ap $<0.05$ was considered as statistically significant.

\section{RESULTS}

\section{The prevalence of STH infection}

The overall prevalence of STH infection in three elementary school in Terong Tawah Village was $81.7 \%$ consisting $42.1 \%$ of male and $39.6 \%$ of female as presented in TABLE 1 . The specific STH found were A. lumbricoides, T. trichiura and mixed of both worms. Among the infected male children, $10.7 \%$ had single infection of $A$. lumbricoides, $20.8 \%$ had single infection of $T$. trichiura and $10.7 \%$ had mixed infection of both worms. Whereas among the infected female children, $10.7 \%$ had singel infection of $A$. lumbricoides, $15.2 \%$ had single infection of $T$. trichiura and $13.7 \%$ had mixed infection of both worms. 
TABLE 1. The prevalence of STH infection ( $\mathrm{n}$ or \%) in elementary school children in Terong Tawah area based on gender

\begin{tabular}{|c|c|c|c|c|c|c|c|c|}
\hline \multirow{3}{*}{ Schools } & \multicolumn{6}{|c|}{ Prevalence of STH infection } & \multirow{3}{*}{ Negative } & \multirow{3}{*}{$\mathrm{n}$} \\
\hline & \multicolumn{3}{|c|}{ Female } & \multicolumn{3}{|c|}{ Male } & & \\
\hline & A.l & T.t & $A . l+T . t$ & A.l & T.t & $A . l+T . t$ & & \\
\hline $\begin{array}{l}\text { Elementary } \\
\text { School } 1\end{array}$ & $\begin{array}{c}9 \\
(13.0)\end{array}$ & $\begin{array}{c}9 \\
(13.0)\end{array}$ & $\begin{array}{c}10 \\
(14.5)\end{array}$ & $\begin{array}{c}7 \\
(10.1)\end{array}$ & $\begin{array}{c}14 \\
(20.3)\end{array}$ & $\begin{array}{c}8 \\
(11.6)\end{array}$ & $\begin{array}{c}12 \\
(17.4)\end{array}$ & 69 \\
\hline $\begin{array}{l}\text { Elementary } \\
\text { School } 2\end{array}$ & $\begin{array}{c}4 \\
(6.4)\end{array}$ & $\begin{array}{c}13 \\
(21.0)\end{array}$ & $\begin{array}{c}7 \\
(11.3)\end{array}$ & $\begin{array}{c}8 \\
(12.9)\end{array}$ & $\begin{array}{c}8 \\
(12.9)\end{array}$ & $\begin{array}{c}5 \\
(8.1)\end{array}$ & $\begin{array}{c}17 \\
(27.4)\end{array}$ & 62 \\
\hline $\begin{array}{l}\text { Elementary } \\
\text { School } 2\end{array}$ & $\begin{array}{c}8 \\
(12.1)\end{array}$ & $\begin{array}{c}8 \\
(12.1)\end{array}$ & $\begin{array}{c}10 \\
(15.1)\end{array}$ & $\begin{array}{c}6 \\
(9.1)\end{array}$ & $\begin{array}{c}19 \\
(28.8)\end{array}$ & $\begin{array}{c}8 \\
(12.1)\end{array}$ & $\begin{array}{c}7 \\
(10.1)\end{array}$ & 66 \\
\hline Total & $\begin{array}{c}21 \\
(10.7)\end{array}$ & $\begin{array}{c}30 \\
(15.2)\end{array}$ & $\begin{array}{c}27 \\
(13.7)\end{array}$ & $\begin{array}{c}21 \\
(10.7)\end{array}$ & $\begin{array}{c}41 \\
(20.8)\end{array}$ & $\begin{array}{c}21 \\
(10.7)\end{array}$ & $\begin{array}{c}36 \\
(18.3)\end{array}$ & 197 \\
\hline
\end{tabular}

$\mathrm{n}:$ total sample tested $; A l: A$. lumbricoides $; T t: T$. trichiura

The prevalence of STH infection in the elementary school 44 Ampenan as control school was lower (12.6\% consisting $5.0 \%$ of male and $7.6 \%$ of female) than in elementary school Terong Tawah as presented in TABLE2. The specific STH found were also $A$. lumbricoides, T. trichiura and mixed of both worms. Among the infected male children,
$1.0 \%$ had single infection of A. lumbricoides, $4.0 \%$ had single infection of T. trichiura and had no mixed infection of both worms observed. Whereas among the infected female children, $3.5 \%$ had singel infection of $A$. lumbricoides, $3.0 \%$ had single infection of $T$. trichiura and $1.0 \%$ had mixed infection of both worms.

TABLE 2. The prevalence of STH in Elementary School 44 Ampenan students

\begin{tabular}{|c|c|c|c|c|c|c|c|c|}
\hline \multirow{3}{*}{$\begin{array}{l}\text { Elementary } \\
\text { School } \\
\text { Ampenan }\end{array}$} & \multicolumn{6}{|c|}{ Prevalence of STH infection } & \multirow{3}{*}{ Negative } & \multirow{3}{*}{$\mathrm{n}$} \\
\hline & \multicolumn{3}{|c|}{ Female } & \multicolumn{3}{|c|}{ Male } & & \\
\hline & A.1 & T.t & A.1+ T.t & A.1 & T.t & A.1+ T.t & & \\
\hline $3^{\text {rd }}$ grade & $\begin{array}{c}4 \\
(7.7)\end{array}$ & $\begin{array}{c}2 \\
(3.8)\end{array}$ & $\begin{array}{c}1 \\
(1.9)\end{array}$ & $\begin{array}{c}0 \\
(0.0)\end{array}$ & $\begin{array}{c}2 \\
(3.8)\end{array}$ & $\begin{array}{c}0 \\
(0.0)\end{array}$ & $\begin{array}{c}43 \\
(82.7)\end{array}$ & 52 \\
\hline $4^{\text {th }}$ grade & $\begin{array}{c}0 \\
(0.0)\end{array}$ & $\begin{array}{c}2 \\
(4.3)\end{array}$ & $\begin{array}{c}1 \\
(2.1)\end{array}$ & $\begin{array}{c}1 \\
(2.1)\end{array}$ & $\begin{array}{c}1 \\
(2.1)\end{array}$ & $\begin{array}{c}0 \\
(0.0)\end{array}$ & $\begin{array}{c}41 \\
(89.1)\end{array}$ & 46 \\
\hline $5^{\text {th }}$ grade & $\begin{array}{c}2 \\
(4.0)\end{array}$ & $\begin{array}{c}2 \\
(4.0)\end{array}$ & $\begin{array}{c}0 \\
(0.0)\end{array}$ & $\begin{array}{c}1 \\
(2.0)\end{array}$ & $\begin{array}{c}1 \\
(2.0)\end{array}$ & $\begin{array}{c}0 \\
(0.0)\end{array}$ & $\begin{array}{c}45 \\
(88.2)\end{array}$ & 51 \\
\hline $6^{\text {th }}$ grade & $\begin{array}{c}1 \\
(2.1)\end{array}$ & $\begin{array}{c}0 \\
(0.0)\end{array}$ & $\begin{array}{c}0 \\
(0.0)\end{array}$ & $\begin{array}{c}0 \\
(0.0)\end{array}$ & $\begin{array}{c}4 \\
(8.3) \\
\end{array}$ & $\begin{array}{c}0 \\
(0.0)\end{array}$ & $\begin{array}{c}43 \\
(89.6) \\
\end{array}$ & 48 \\
\hline Total & $\begin{array}{c}7 \\
(3.5) \\
\end{array}$ & $\begin{array}{c}6 \\
(3.0) \\
\end{array}$ & $\begin{array}{c}2 \\
(1.0) \\
\end{array}$ & $\begin{array}{c}2 \\
(1.0) \\
\end{array}$ & $\begin{array}{c}8 \\
(4.0) \\
\end{array}$ & $\begin{array}{c}0 \\
(0.0) \\
\end{array}$ & $\begin{array}{c}172 \\
(87.3) \\
\end{array}$ & 197 \\
\hline
\end{tabular}

$\mathrm{n}$ : total sample tested ; Al : A. lumbricoides ; Tt : T. trichiura

\section{Intensity of STH infection}

The intensity of infection in elementary school children in Terong Tawah was mild (91.9\%) to moderate $(12.2 \%)$, whereas in elementary school 44 Ampenan only mild intensity of STH infection was observed (13.7\%) (TABLE 3). 
TABLE 3. The intensity of STH infection (n/\%) in children of elementary school of Terong Tawah and Ampenan 44

\begin{tabular}{|c|c|c|c|c|c|}
\hline \multirow{3}{*}{$\begin{array}{l}\text { Elementary } \\
\text { school }\end{array}$} & \multicolumn{4}{|c|}{ Intensity of infection } & \multirow{3}{*}{$\mathrm{n}$} \\
\hline & \multicolumn{2}{|c|}{ A. lum bricoides } & \multicolumn{2}{|c|}{ T. trichiura } & \\
\hline & Mild & Moderate & Mild & M oderate & \\
\hline Terong Tawah & $80(40.60)$ & $8(4.1)$ & $101(51.3)$ & $16(8.1)$ & 197 \\
\hline Ampenan & $11(5.6)$ & 0 & $16(8.1)$ & 0 & 197 \\
\hline Total & $91(23.1)$ & $8(2.0)$ & $117(29.7)$ & $16(4.1)$ & 394 \\
\hline
\end{tabular}

$\mathrm{n}:$ total sample tested

\section{Soil contamination}

Soil Transmitted Helminths eggs contaminated soil around the home of students of elementary schools in Terong Tawah and Elementary School 44 Ampenan are presented in TABLE 4. The STH eggs that contaminated soil in Terong Tawah were higher (62.3\%) than in Ampenan (2\%). Among 122 soil samples that contaminated with STH eggs in Terong Tawah, $24.4 \%$ samples were contaminated with A. lumbricoides eggs, $23.9 \%$ samples were contaminated with $T$. trichiura eggs and $14.0 \%$ were contaminated with mixed $A$. lumbricoides and T. trichiura eggs. Whereas, among four soil samples that contaminated with STH eggs in Ampenan, 1.5\% samples were contaminated with A. lumbricoides eggs, $0.5 \%$ samples were contaminated with T. trichiura eggs.

TABLE4. STH eggs that contaminated soil around the home of students of elementary schools in Terong Tawah and Elementary School 44 Ampenan

\begin{tabular}{|c|c|c|c|c|c|}
\hline \multirow[b]{2}{*}{ Elementary School } & \multicolumn{3}{|c|}{ Soil contamination } & \multirow[b]{2}{*}{ Negative } & \multirow[b]{2}{*}{$\mathrm{n}$} \\
\hline & A. lumbricoides & T. trichura & $\begin{array}{l}\text { A. lumbricoides }+ \\
\text { T. trichura }\end{array}$ & & \\
\hline Terong Sawah & $47(23.9)$ & $48(24.4)$ & $27(14.0)$ & $75(37.7)$ & 197 \\
\hline Ampeanan 44 & $3(1.5)$ & $1(0.5)$ & 0 & $193(98.0)$ & 197 \\
\hline Total & $50(12.7)$ & $49(12.4)$ & $27(6.8)$ & $268(68.0)$ & 394 \\
\hline
\end{tabular}

\section{The correlation between hygiene, sanitation and STH infection}

The correlation between hygiene and sanitation with STH infection in students of elementary schools in Terong Tawah, West Lombok and Elementary School 44 Ampenan, Mataram City is presented in TABLE 5. A significant correlation between nail hygiene, hand washing, soil around the house and STH infection was observed in this study $(\mathrm{p}<0.05)$. However, using footwear, latrine, clean water availability, and house floor were not correlated with STH infection $(\mathrm{p}>0.05)$. 
TABLE 5. Correlation between hygiene and sanitation with STH infection (n/\%) in students of elementary schools in Terong Tawah, West Lombok and Elementary School 44 Ampenan, Mataram City

\begin{tabular}{lccccc}
\hline & \multicolumn{3}{c}{ Soil contamination } & Negative & $\mathrm{n}$ \\
\cline { 2 - 5 } Flementary School & A. & lumbricoides & T. trichura & $\begin{array}{c}\text { A. lumbricoides }+ \\
\text { T. trichura }\end{array}$ & \\
\hline Terong Sawah & $47(23.9)$ & $48(24.4)$ & $27(14.0)$ & $75(37.7)$ & 197 \\
Ampeanan 44 & $3(1.5)$ & $1(0.5)$ & 0 & $193(98.0)$ & 197 \\
\hline Total & $50(12.7)$ & $49(12.4)$ & $27(6.8)$ & $268(68.0)$ & 394 \\
\hline
\end{tabular}

$\mathrm{n}$ : total sample tested

\section{DISCUSSION}

This study showed that the prevalences of STH infections among elementary school children in Terong Tawah was $81.7 \%$ consisting $T$. trichiura (36.0\%) followed by A. lumbricoides (20.4\%) and mixed infections between $T$. trichiura and A. lumbricoides (24.4\%). Several studies about the prevalences of STH infection among school children have been conducted with varying results. A study conducted on school aged children in Zarima town, North West Ethiopia reported that $82.4 \%$ of study subjects were infected by STH and Schistosoma mansoni. Among these STH infections, $A$. lumbricoides $(22.0 \%)$ was the predominant followed by hookworms (19.0\%) and T. trichiura (2.5\%). ${ }^{12}$ Another study also conducted on school aged children in, Delta State, Nigeria, reported that $54.7 \%$ children were infected by STH. Among these infection, $A$. lumbricoides had the highest overall infection rate of $48.41 \%$, followed by hookworm (29.8\%) and T. trichiura (17.4\%). ${ }^{13}$ In Tanzania STH are quite prevalent among school aged children. It was reported that $49.4 \%$ the children were infected with at least one helminth. Trichuris trichiura was the predominant helminth (35.5\%), followed by A. lubricoides (12.2\%) and hookworm (11.9\%). ${ }^{14}$

Although the prevalences of STH infection vary among several studies. However, almost all of studies agree that the intensity and prevalence of STH infection exhibit age-dependent patterns. Peak levels of STH infection normally occur in hosts aged between 10 and 14 years. ${ }^{15}$ Norhayati et al. ${ }^{16}$ reported that the prevalence and intensity of STH infection are highest among children 4 to 15 years of age. Age-dependent patterns of infection prevalence are generally similar among the major helminth species, exhibiting a rise in childhood to a relatively stable asymptoms in adulthood. ${ }^{17}$ Therefore school aged children are the group of population who bear the greatest prevalence and intensity of worm infection.

The prevalence of STH is associated with geographical area of the schools, hygiene and sanitation. ${ }^{17,18}$ This study showed that the prevalences of STH infections among elementary school children in Terong Tawah was (81.7\%) was higher than those in Ampenan (12.6\%). Terong Tawah is one of villages located in Labuapi Sub District, West Lombok District. The majority of incomes is generated by farming, some engage in jobs at government officers with a few in private sector. Terong Tawah village is buffer zone of Mataram City. However as a buffer zone, the infrastructure is relatively inadequate. Moreover, the hygiene and sanitation is poor in this village. The habits of bathing, washing and defecation in rivers are commonly conducted by much people. The personal hygiene of elementary school children is also poor. The children playing in rice fields or other fields without using footwear and no hand 
washing before eating are often observed. In contrast in Ampenan Mataram as area control, the hygiene and sanitation is more better than Terong Tawah. Therefore, it can be presumed that the poor hygiene and sanitation in Terong Tawah are the cause the high prevalences of STH infection.

Further analysis showed that there is a significant relationship between nail hygiene, hand washing, and soil around the house with STH infection among elementary school children both in Terong Tawah and Ampenan. Dirty nail and ineffective or lack in hand washing can be the source for STH transmission and are associated with the high prevalence of STH infection. ${ }^{19-21}$ The worm eggs hatch and grow in the gut, and are passed through bowel movements and directly from the anus. During the night the hatched the worms exit through the anus laying eggs on their way. These eggs cause itching and can then be passed to the fingers by scratching allowing them to re-enter the system via the mouth or to be spread easily by contaminating other surfaces.

The study found that the worm eggs contaminated soil in Terong Tawah were higher (62.3\%) than in Ampenan (2\%). Moreover, a significant correlation between worm eggs contaminated soil was observed. Surveys of worm eggs contaminated soil have been performed in several countries, especially in South America and Asia. ${ }^{22}$ It is reported that a recovery rate of 720\% for Ascaris spp and hookworm eggs in urban slums in Brazil. ${ }^{23}$ In suburban areas in Indonesia, ${ }^{24}$ a fishing village in Thailand, ${ }^{25}$ and surrounding fields and houses in Nepal, ${ }^{26} 20-83 \%$ of $A$. lumbricoides, T. trichiura, and hookworm eggs have been recovered from soil.

\section{CONCLUSION}

It can be concluded taht the prevalence of STH infection among the elementary school students in Terong Tawah, West Lombok was higher than that in Ampenan, Mataram City. There is a relationship between nail hygiene, hand washing as well as worm eggs contaminated soil around the house and STH infections. Public health intervention to reduce the prevalence of STH infection in Terong Tawah through mass medication, education, improvement personal hygiene and sanitation is needed.

\section{ACKNOWLEDGEMENTS}

We would like to thank all volunteers for their participation in this study.

\section{REFERENCES}

1. Margono SS. Important human helminthiasis in Indonesia. In: Crompton DWT, Montresor A, Nesheim MC, Savioli L editors. Controlling disease due to helminth infections. Geneva: World Health Organization, 2003: 3-14.

2. Anonim. Pedoman pengendalian program nasional pemberantasan cacingan di era desentralisasi. Jakarta: Departemen Kesehatan RI. 2006.

3. Abidin SAN and Hadidjaja A. The effect of soiltransmitted helminth infection on the cognitive function of schoolchildren. In: Crompton DWT, Montresor A, Nesheim MC, Savioli L editors. Controlling disease due to helminth infections. Geneva: World Health Organization, 2003: 3-14.

4. Brooker S, Clements ARCA, Bundy DAP. Global epidemiology, ecology and control of soiltransmittedhelminth infections. Adv Parasitol 2006; 62: 221-261.

5. Widjana DP and Sutisna P. Prevalence of soiltransmitted helminth infections in the rural population of Bali, Indonesia. Southeast Asian J Trop Public Helth 2000; 31(3):454-9.

6. Drake LJ, Jukes MCH, Sternberg RJ, Bundy DAP. Geohelminth infections (Ascariasis, Trichuriasis and Hookworm): cognitive and developmental impacts. Seminars in Pediatric Infectious Diseases 2000; 11:245-251.

7. Hotez PJ, Brooker S, Bethony JM, Bottazzi ME, Loukas A, Xiao S. Current concepts: Hookworm infection. N Engl J Med 2004; 351:799-807.

8. Stephenson LS, Latham MC, Ottesen EA. Malnutrition and parasitic helminth infections. Parasitology 2000; 121(Suppl):S23-S38. 
9. Fenwick A, Savioli L, Engels D, Bergquist RN, Todd MH. Drugs for the control of parasitic diseases: current status and development in schistosomiasis. Trends Parasitol 2003; 19:509-15.

10. World Health Organization. Basic laboratory methods in medical parasitology. Geneva: World Health Organization, 1991.

11. Montresor A, Crompton DWT, Gyorkos TW, Savioli L. Helminth control in school-age children: a guide for managers of control programmes. Geneva: World Health Organization, 2002.

12. Abebe A, Asmamaw A, Zelalem A, Yitayal S, Takele T, Biniam M, Wubet B, Simon G, Baye G. Soiltransmitted helminths and Schistosoma mansoni infections among school children in Zarima town, Northwest Ethiopia. BMC Infec Dis 2011; 11:189. Doi:10.1186/1471-2334-11-189

13. Andy EO and Palmer AD. Soil-transmitted helminthiasis among school age children in Ethiope East Local Government Area, Delta State, Nigeria. African J Biotechnol 2005; 4 (9): 938-41.

14. Knopp S, Mgeni AF, Khamis IS, Steinmann P, Stothard JR, Rollinson D, Marti H, Utzinger J. Diagnosis of soil-transmitted helminths in the era of preventive chemotherapy: effect of multiple stool sampling and use of different diagnostic techniques. PloS Neg1 Trop Dis 2008; 2(11):331-8.

15. Galvani AP. Age-dependent epidemiological patterns and strain diversity in helminth parasites. J Parasitol 2005; 91(1): 24-30.

16. Norhayati M, Fatmah MS, Yusof S, Edariah AB. Intestinal parasitic infections in man. Med J Malaysia 2003; 58(2):296-305.

17. Hotez PJ, Bundy DAP, Beegle K, Brooker S, Drake L, De Silva $\mathrm{N}$ et al. Helminth infections: soiltransmitted helminth infections and schistosomiasis. In: Jamison DT, Breman JG, Measham AR, Alleyne G, Claeson M, editors. Disease control priorities in developing countries, $2^{\text {nd }}$ ed. New York: Oxford University Press, 2006: 467-82.

18. Ziegelbauer K, Speich B, Mäusezah D, Bos R, Keiser J, Utzinger J. Effect of sanitation on soiltransmitted helminth infection: systematic review and meta-analysis. PLoS Med 2012; 9(1): e1001162. Doi:10.1371/journal.pmed.1001162.

19. Gunawan AT. Profil infeksi telur cacing pada balita di Kecamatan Banyumas [Tesis]. Jakarta: Universitas Indonesia; 2002.

20. Hoa NTV, Noda S, Uga S, Thuan LK, Aoki Y, Fujimaki Y. Parasite egg contamination of hands in a suburban area of Hanoi, Vietnam. Trop Med Health 2010; 38: 75-9.

21. Fung IC and Cairncross S. Ascariasis and handwashing. Trans R Soc Trop Med Hyg 2009; 103(3): 215-22.

22. Horiuchis $\mathrm{S}$, Paller VG, Ugas S. Soil contamination by parasite eggs in rural village in the Philippines. Trop Biomed 2013;103(3):215-22.

23. Korkes F, Kumagai FU, Belfort RN, Szejnfeld D, Abud TG, Kleinman A, et al. Relationship between intestinal parasitic infection in children and soil contamination in an urban slum. J Trop Pediatr 2009; 55: $42-5$.

24. Uga S, Ono K, Kataoka N, Safriah A, Tantular .S, Dachlan YP, et al. Contamination of soil with parasite eggs in Surabaya, Indonesia. Southeast Asian J Trop Med Pub Health 1995; 26: 730-4.

25. Chongsuvivatwong V, Uga S, Nagnaen W. Soil contamination and infections by soil-transmitted helminthes in an endemic village in southern Thailand. Southeast Asian J Trop Med Pub Health 1999;30: 64-7.

26. Rai SK, Uga S, Ono K, Rai G, Matsumura T. Contamination of soil with helminth parasite eggs in Nepal. Southeast Asian J Trop Med Public Health 2000; 31: 388-93. 